\title{
Регресивний результат антропологічної статистики Великого терору в СРСР (1937-1938 рр.)
}

\begin{abstract}
Анотація: На основі нових, розсекречених матеріалів радянських спецслужб, проаналізовано кількісні та якісні характеристики результатів репресивних акцій, проведено джерелознавчий аналіз документів державної безпеки періоду проведення масових репресій стосовно їх інформативності та ступеня повноти, репрезентативності та достовірності, варіантів фальсифікащій тощо. Розглянуто механізм функціонування позасудових органів сталінських репресій - трійок, двійок, Особливої наради. Роль і наслідки діяльності особливих трійок, ї склад і характер справ. У пропонованому дослідженні використано джерело, яке ще донедавна було малодоступним - матеріали розслідування службової діяльності та злочинів співробітників органів державної безпеки. Мета дослідження полягає у статистичному аналізі регресивних результатів антропологічної статистики на прикладі роботи миколаївської трійкu.
\end{abstract}

Ключові слова: Антропологічна статистика, СРСР, Україна, Миколаївська область, НКВС, Великий терор 1937-1938 рр., масові репресії, трійка, Особлива нарада

Проблематиці Великого терору 1937-1938 рр. присвячено значну кількість публікацій у вітчизняній і зарубіжній історіографії. Зокрема, у дослідників з'явилася можливість проаналізувати кількісні та якісні характеристики результатів репресивних акцій ${ }^{1}$, провести джерелознавчий аналіз документів державної безпеки періоду проведення масових репресій стосовно їх інформативності та ступеня повноти, репрезентативності та достовірності, варіантів фальсифікацій тощо ${ }^{2}$. Разом 3 тим, недостатньо опрацьованим залишається механізм функціонування позасудових органів сталінських репресій - трійок, двійок, Особливої наради. Роль і наслідки діяльності особливих трійок, їх склад і характер справ, винесених на їхній розгляд, у соціальному, демографічному та національному розрізі

\footnotetext{
"Макарчук Сергій Сергійович - кандидат історичних наук, доцент, керівник Обласного центру пошукових досліджень та редакційно-видавничої діяльності (Миколаїв, Україна);

ORCID: https://orcid.org/0000-0003-4279-1093; e-mail: ocpdtarvd@ukr.net

Федоренко Михайло Олександрович - кандидат історичних наук, доцент кафедри соціально-гуманітарних дисциплін Національного університету кораблебудування імені адмірала Макарова (Миколаїв, Україна); ORCID: https://orcid.org/0000-0003-1713-6492; e-mail: m.o.fedorenko@gmail.com

${ }^{1}$ Нікольський В.М. Репресивна діяльність органів державної безпеки СРСР в Україні (кінець 1920-1930-ті рр.). Історико-статистичне дослідження. Донецьк, 2003.

${ }^{2}$ Гранкіна О.В. Деякі аспекти джерелознавчого аналізу архівно-слідчих справ у 1920-1950рр. // Український історичний журнал. 1997. № 4. С. 49-57; Архівно-слідчі справи репресованих: науково-методичні аспекти використання: зб. наук. пр./ Український держ. НДІ архівної справи і документознавства, Державний архів Служби безпеки України; ред.. Пиріг Р.Я. [та ін.]. Київ, 1998. 161 с.; Петровський Е.П. Архівно-слідчі справи як джерело вивчення історії репресій в Україні у 1937-1938 роках: автореф. дис.... канд. іст. н.: 07.00.06 Історіографія, джерелознавство та спеціальні історичні дисципліни. Київ, 2006. 22 с.; Подкур Р., Ченщов В. Документы органов государственной безопасности УССР 1920-1930-х годов: источниковедческий анализ. Тернополь, 2010. 372 с. та ін.
} 
найбілыш повно представлені у збірнику документів, присвяченому так званій «куркульській операції, яка, власне, започаткувала Великий терор³.

У пропонованому дослідженні використано джерело, яке ще донедавна було малодоступним - матеріали розслідування службової діяльності та злочинів співробітників органів державної безпеки. Вперше в Україні цей масив документів був опублікований у 2017-2018 pр. ${ }^{4}$

В основу наукової розвідки покладено 13-томну архівно-кримінальну справу про розслідування злочинів посадових осіб Миколаївського УНКВС на завершальному етапі «Великого терору» ${ }^{5}$.

Збірники документів і матеріалів містять протоколи та стенограми партійних зборів та оперативних нарад співробітників обласних УНКВС, протоколи допитів, показання свідків, матеріали перевірок тощо, які розкривають як процедуру функціонування трійок, так і методи фальсифікації справ.

До наукового обігу увійшли протоколи судових засідань військових трибуналів, що розглядали кримінальні справи співробітників НКВС за порушення «соціалістичної законності» під час проведення масових операцій. Вони виявлені в архівно-кримінальних справах чекістів, окремі витяги зустрічаються у справах репресованих громадян як ілюстрація діяльності слідчих.

Останнім часом для дослідників стали доступними особові справи працівників НКВС, які мають безперечну цінність у плані з'ясування імен конкретних виконавців репресивної політики політичного керівництва СРСР та УРСР.

Важливе значення для підготовки статті мають оприлюднені результати досліджень вітчизняних і зарубіжних учасників міжнародного науково-видавничого проекту «Відлуння Великого терору: співробітники НКВС на лаві підсудних (1938-1941 pp.)» - В. Васильєва, Л. Віоли, О. Савіна, А. Теплякова, Р. Подкура, С. Кокіна, В. Золотарьова, Дж. Россмана й ін. ${ }^{7}$

Цінний матеріал для порівняльного аналізу автори взяли 3 публікацій О.Гранкіної, В. Репринцева, О. Рубльова ${ }^{8}$ й у документальних видання Галузевого державного архіву СБУ ${ }^{9}$, присвячених так званим національним операціям.

Історіографія Великого терору налічує вже тисячі наукових і науково-популярних праць. Вчені, публіцисти, журналісти вивчали його мотиви, діяльність вищого керівництва СРСР, посадовців НКВС СРСР і УРСР, механізм здійснення, перебіг, безпосередніх виконавців волі більшовицької партії, демографічні наслідки, увічнення пам'яті його жертв. Масові репресивні операції в СРСР розпочалися, на думку білышості дослідників, рішенням політбюро ЦК ВКП(б) від 2 липня 1937 р. «Про антирадянські елементи». У ньому пропонувалося «...взяти на облік усіх

\footnotetext{
${ }^{3}$ Великий терор в Україні. «Куркульська операція» 1937-1938 рр. у 2-х ч. / Упоряд.: С.Кокін, М.Юнге. - К.: Вид. дім «Києво-Могилянська академія», 2010.

${ }^{4}$ Відлуння Великого терору. Збірник документів у 3-х томах/ Автори-укладачі: Валерій Васильєв, Лінн Віола, Роман Подкур. - К.: Видавець В.Захарченко, 2017-2018.

${ }^{5}$ Галузевий держархів Служби безпеки України (ГДА СБУ). Ф. 5. Спр. 67990. Т. 1-13.

${ }^{6}$ Васильєв В., Подкур Р. Радянські карателі. Співробітники НКВС - виконавці «Великого терору» на Поділлі. Київ: Видавець В. Захаренко, 2017. С. 22.

${ }^{7}$ Див.: 3 архівів ВУЧК-ГПУ-НКВД-КГБ. 2015. № 1 (44); 3 архівів ВУЧК-ГПУ-НКВД-КГБ. 2015. № 2 (45).

${ }^{8}$ Гранкіна О. Архівно-слідчі справи другої половини 1937 року щодо представників національних меншин України. Джерелознавчий аналіз документів// 3 архівів ВУЧК-ГПУ-НКВД-КГБ. 1998. № 1/2 (6/7). С. 174-182; Рубльов О., Репринщев В. Репресії проти поляків в Україні у 30-ті роки // 3 архівів ВУЧК-ГПУ-НКВД-КГБ. 1995. № 1/2 (2/3). C. 116-156.

${ }^{9}$ Польща та Україна у тридцятих-сорокових роках XX століття: Невідомі документи з архівів спеціальних служб. Т. 8: Великий терор. Польська операція 1937-1938. У 2-хч. Варшава-Київ, 2010; «Великий терор» в Україні: Німецька операція 1937-1938 років; Зб. Документів/ Упоряд.: А. Айсфельд, Н. Сердюк. Київ: К.І.С., 2018. 1248 c.
} 
куркулів, що повернулися на батьківщину, і карних злочинців 3 тим, щоб найбілыш ворожі 3 них були негайно розстріляні у порядку адміністративного переведення їхніх справ через трійки, а інші, менш активні, але все-таки ворожі елементи, були переписані та вислані до районів за вказівками НКВС. ЦК ВКП(б) пропонує у п'ятиденний термін подати до ЦК склад трійок, а також кількість осіб, що підлягають розстрілу, так само й кількість тих, хто підлягає засланню» ${ }^{10}$. Тому мета дослідження полягає у статистичному аналізі регресивних результатів антропологічної статистики на прикладі роботи миколаївської трійки.

Після отримання телеграми з Москви в УРСР розпочалася гарячкова підготовка до масової операції. Вже 4 липня 1937 р. на засіданні політбюро ЦК КП(б)У були сформовані обласні трійки у складі першого секретаря обкому, начальника обласного УНКВС та обласного прокурора. Водночас, за вказівкою наркома внутрішніх справ СРСР М. Єжова, співробітники НКВС УРСР повинні були взяти на облік куркулів і кримінальників, розділивши їх на дві категорії. До першої включалися ті, що підлягали арешту та розстрілу, до другої ті, що підлягали висиланню у райони за вказівкою НКВС СРСР. Нарком внутрішніх справ УРСР І. Леплевський мав надати цю інформацію до 8 липня 1937 p. ${ }^{11}$

Основна роль у проведенні арештів і слідства покладалася на міжрайонні оперативні групи чекістів, створені в окружних центрах і великих населених пунктах. Всього в УРСР було створено 45 міжрайонних опергруп. Зокрема, на території майбутньої Миколаївської області такі групи були утворені у чотирьох містах - Миколаєві, Херсоні, Кірово та Первомайську.

30 липня 1937 p. М. Єжов підписав оперативний наказ № 00447 «Про операцію 3 репресування колишніх куркулів, карних злочинців та інших антирадянських елементів», в якому визначалися категорії населення, що підлягали репресіям, та порядок їх проведення. Операція в Україні повинна була розпочатись 5 серпня та продовжуватись чотири місящі12. У подальшому термін завершення операції був подовжений до 1 січня 1938 р., потім до 15 лютого, початку квітня, а в низці областей «куркульська» операція тривала до 1 серпня.

До керівництва НКВС на місцях доводилися ліміти - своєрідний план-розкладка кількості осіб, які підлягали репресуванню. Для України первинний ліміт був встановлений у 28800 осіб, 3 яких 8000 потрібно було розстріляти (1-ша категорія), а 20800 підлягали позбавленню волі на термін від 8 до 10 років (2-га категорія). У подальшому на клопотання керівників УНКВС до НКВС СРСР ліміти неодноразово збільшувалися. Розгляд справ обласними трійками відбувався за спрощеною процедурою - без участі захисту та самого обвинуваченого і без права на оскарження вироку. Смертний вирок виконувався негайно.

Одночасно з «куркульською» операцією розпочалися масові репресії за «національними лініями». Спочатку, відповідно до оперативного наказу НКВС СРСР №00439 від 25 липня 1937 р. розпочались масові арешти німецького населення. 9 серпня 1937 р. М. Єжов підготував наказ № 00485 про репресії поляків. Далі за наказом № 00593 від 20 вересня 1937 р. були репресовані так звані «харбінці». У жовтні і листопаді 1937 р. НКВС СРСР за вказівкою політбюро ЦК ВКП(б) почав здійснювати «латиську», «фінську», «грецьку», «румунську», «естонську» й інші національні операції. Переважна більшість жертв національних операцій була віднесена до «першої категоріі».13. На тлі «куркульської» та «національних» операцій в УРСР не припинялося винищення інтелігенції та представників партійно-радянської еліти, які обвинувачувалися в «українському буржуазному націоналізмі», «троцькізмі» тощо.

\footnotetext{
${ }^{10}$ Васильєв В., Подкур Р. Радянські карателі... С. 81.

${ }^{11}$ Ibidem.

${ }^{12}$ Васильєв В., Подкур Р. Радянські карателі... С. 84-85.

${ }^{13}$ Кульчищький С. Вертикаль державної безпеки в системі диктатури більшовицьких вождів (1917-1938) // Радянські органи державної безпеки в Україні (1918-1991 рр.): історія, структура, функції. Київ: Інститут історії України НАН України, 2014. С. 85.
} 
У цьому відношенні Миколаївщина не була винятком. Масові репресії розпочалися у районах майбутньої Миколаївської області ще під час іх перебування у складі Одеської та Дніпропетровської областей. Область була утворена 22 вересня 1937 p. із 41 району Одеської та 9 районів Дніпропетровської областей. Вже на початку жовтня 1937 р. було створене обласне управління НКВС, начальником якого 1 жовтня став капітан державної безпеки Й.Б. Фішер. Він же, вочевидь, очолив Миколаївську обласну трійку, членами якої були перший секретар обкому Волков та обласний прокурор Ланчуковський.

У січні 1938 р. Й. Фішер у звітній доповіді про діяльність Миколаївського УНКВС зазначив, що до 22 вересня 1937 р. на території області було засуджено 1788 осіб. Від УНКВС Одеської та Дніпропетровської областей було прийнято 1212 арештованих. За час після організації Миколаївської області до січня 1938 р. заарештовано 6063 особи, таким чином всього було «опрацьовано» 7175 арештованих ${ }^{14}$.

У довідці від 10 січня 1938 р. вміщено красномовні свідчення про «успіхи» миколаївських чекістів за час першого етапу «Великого терору». Зазначалося, що за період з 1.10 .1937 р. по 10.01.1938 р. було заарештовано 202 «правотроцькіста», 17 учасників «воєнно-фашистської змови», 848 «польських шпигунів», 984 «німецьких шпигунів», 949 «українських націоналістів», 143 «румунських шпигуна», 1290 «куркулів-контрреволюціонерів» та ін. На клопотання НКВС УРСР та Й. Фішера Москва періодично давала згоду на додаткові ліміти для Миколаївської обласної трійки: 1 грудня 1937 р. - 200 осіб по 1-й категорії і 600 по 2-й ${ }^{15}, 9$ грудня - 110 по 1-й категорії ${ }^{16}, 17$ грудня 400 чол. по 1-й категорії ${ }^{17}$. На січень 1938 р. ліміт для Миколаївської обл. трійки становив 3910 осіб, 3 них 1400 по 1-й категорії та 2 510- по другій ${ }^{18}$.

Проте навіть такі шалені темпи проведення арештів згодом перестали задовольняти «режисерів» Великого терору. 25 січня 1938 р. замість І. Леплевського, якого призначили начальником 6-го відділу ГУДБ НКВС СРСР, а згодом розстріляли, новим наркомом внутрішніх справ УРСР був призначений О.І. Успенський. Відповідно, кадрові зміни відбулися як в апараті УДБ НКВС УРСР, так і в обласних управліннях НКВС. Й. Фішер був відізваний у розпорядження НКВС СРСР, а 3 березня 1938 р. місце начальника УНКВС по Миколаївській області посів капітан держбезпеки Петро Васильович Карамишев.

Новий очільник миколаївських чекістів продовжував боротьбу 3 «ворогами народу»: виявлення правотроцькістів, шпигунсько-диверсійних груп, націоналістів, шкідників і саботажників. 2 серпня 1938 р. на Миколаївському суднобудівному заводі № 200 (ім. 61 комунара) сталася пожежа, що було кваліфіковано як диверсійний акт, здійснений троцькістською саботажницькою організацією. У результаті співробітниками УНКВС була заарештована група працівників цього підприємства. Роль центральної фігури «троцькістської диверсійної організації була відведена начальнику корпусного цеху Л.П. Фоміну, а розслідування справи доручене СПВ УНКВС на чолі 3 Я.Л.Трушкіним. Однак сталось неймовірне - замість засудження «організаторів диверсії, «шкідників-троцькістів» на лаві підсудних опинились керівники Миколаївського УНКВС П.В. Карамишев, начальник секретно-політичного відділу управління Я.Л.Трушкін, заступник начальника СПВ М.В. Гарбузов і начальник одного з відділень СПВ К.А. Воронін. За ст. 206-17 п. «б» (посадові злочини) вироком Воєнного трибуналу військ НКВС Київського особливого воєнного округу в березні 1941 р. Карамишев і Трушкін були засуджені до ВМП - розстрілу, а Воронін і

\footnotetext{
${ }^{14}$ Великий терор в Україні. «Куркульська операція» 1937-1938 рр.» / упоряд. С. Кокін, М. Юнге. Київ: Вид. дім «Києво-Могилянська академія», 2010. С. 571.

${ }^{15}$ Великий терор в Україні. «Куркульська операція» 1937-1938 рр.». Ч. 1. С. 178.

${ }^{16}$ Ibid. C. 180.

${ }^{17}$ Ibidem.

${ }^{18}$ Ibid. C. 185.
} 
Гарбузов - до 10 та 8 років позбавлення волі відповідно ${ }^{19}$.

На нашу думку, причина напівзакритих процесів над чекістами полягала у демонстрації відновлення партійного контролю над органами НКВС і перекладання на співробітників НКВС провини у «порушенні соціалістичної законності». Вище політичне керівництво вважало, що таким тактичним маневром буде знята напруга серед працівників партійно-радянського апарату та загалом у суспільстві. Й. Сталін був упевнений, що репресивні акції виконали завдання - у радянському суспільстві був посіяний страх, знищено навіть потенційну опозицію режиму та попереджено можливість утворення «п'ятої колони».

Матеріали розслідування злочинної діяльності Карамишева й інших співробітників Миколаївського УНКВС зосереджені у 13-томній архівно-кримінальній справі № 67990 Галузевого державного архіву СБ України, значною мірою розкривають методи ведення слідства під час Великого терору 1937-1938 pр., технологію фальсифікації справ і підробки слідчих документів, допомагають обєктивному аналізу джерел з цієї проблематики.

Досить детальні показання про роботу Миколаївської особливої трійки УНКВС надав на допиті від 14 січня 1940 р. ії секретар Шейнберг:

«...Голова трійки Карамишев, члени - секретар обкому Старигін і обл[асний] прокурор Ланчуковський.

Крім того, неодноразово на засідання трійки замість Старигіна і Ланчуковського, як член трійки, засідали Максимов - 2-й секретар обкому і Карпенко - заступник облпрокурора у спецсправах.

Технічні працівники: секретар Шейнберг і його помічники - співробітники І спецвідділу Самойленко і Славинський, машиністка Февральська і в допомогу їй мобілізовані машиністки Каганович, Суліна, Коваленко і ще дві машиністки з районів.

Крім того, у різні часи були мобілізовані співробітники [УНКВС] Зільбермінц, Коваленко, Шевченко, Базай, Бромберг, Тустановський, Присенко, Телетко і ще дві особи.

Доповідачами на трійці були начальники відділів і відділень - Готовцев, Трушкін, Гарбузов, Воронін, Петров, Зайденберг, Побережець та ін[ші]... ${ }^{20}$.

Тут слід пояснити, що йдеться про особливу трійку, створену у відповідності до наказу НКВС СРСР від 17 вересня 1938 р. № 00606 та циркуляру № 189 від 21 вересня 1938 р. для завершення, у першу чергу, операцій по «національних лініях» у складі начальника УНКВС (голова), і членів трійки - першого секретаря обкому й обласного прокурора. Фактично ж мова йшла не про нову структуру, а про відновлення діяльності «куркульської» трійки під іншою назвою і завданнями.

Порядок розгляду справ був наступним.

Після завершення слідства доповідачі з'являлися на засідання трійки зі слідчими справами і 4-ма екземплярами повісток. Три екземпляри роздавалися членам трійки, по четвертим йшла доповідь.

Повістка представляла собою документ з трьох частин: перша - номер слідчої справи й обєєтивні дані обвинуваченого, друга містила короткий виклад суті справи, третя називалась «рішення у справі» (туди проставляли короткі резолюції - «розстріляти», «10 років» тощо). Вгорі вказувалося прізвище доповідача справи на трійці. Внизу проставлялися прізвища керівників відділу та відділення, які проводили слідство. Іноді повістку підписував секретар трійки, тобто Шейнберг. Протоколи засідання друкувалися на основі повісток як своєрідне іхх узагальнення і підписувались членами трійки.

Згідно із свідченнями Шейнберга, Карамишев, як голова трійки, одноосібно скасовував або

\footnotetext{
${ }^{19}$ Детальніше див.: Юнге М. Козлы отпущения» сопротивляются: процессы над нарушителями «социалистической законности» в Николаевской области в 1939-1941 гг. // 3 архівів ВУЧК-ГПУ-НКВД-МГБКГБ. 2015. № 2 (45). С. 6-90.

${ }^{20}$ ГДА СБУ. Ф. 5. Спр. 67990. Т. 5. Арк. 223.
} 
змінював рішення. Протоколи засідань підписувалися через десять і більше днів у кабінетах Старигіна та Ланчуковського. Причому ті підписували їх не читаючи і навіть не переглядаючи ${ }^{21}$. Карамишев довільно вносив до протоколів нові прізвища, змінював попередні рішення.

На допиті Шейнберга були з'ясовані і зовсім дивні факти:

«...Питання: Чи відомі Вам випадки, коли трійка, не дивлячись на неточності у справах, все ж ухвалювала рішення про засудження таких обвинувачених?

Відповідь: Дійсно, такі факти мали місце. На пред'явлених мені повістках видно, що Карамишев, а іноді й інші члени трійки писали на повістках вироки наступного змісту: «Розстріляти і допитувати», «Розстріляти і дорозслідувати» і т.п.

Рішення за такими справами мною в протоколи не вносились, справи повертались у відповідні відділи і через деякий час ці ж справи повертались до мене, і оскільки не змінювалося попереднє рішення трійки, я вносив їх у протоколи.... ${ }^{22}$.

Згідно з наказом НКВС СРСР рішення трійки про засудження до ВМП - розстрілу, повинно було виконуватись негайно. На тому ж допиті, який проводили старші слідчі УДБ НКВС УРСР Бурдан і Точилкін, Шейнберг дав наступні свідчення:

«...Питання: Чи відомі Вам випадки, коли особи, засуджені трійкою до розстрілу, по місяцю і більше знаходились під вартою і викликалися на допит до слідчих, і звичайно, вироки над ними не виконувались?

Відповідь: Так, такі випадки мені відомі. Відповідно до вказівок Карамишева, я на групових приписах коменданту робив помітки, які означали, що над цими особами вироки не можна

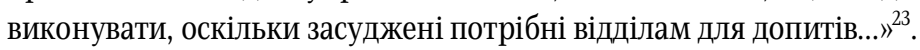

Безпосереднім виконавцем вироків про розстріл був комендант Миколаївського УНКВС Ф.А. Крюковський. На допиті 14 січня 1940 р. він підтвердив слідчим Бурдану і Точилкіну факти затримки виконання вироків за розпорядженням Карамишева.

Він же привів і інші кричущі порушення:

«...Мені пригадується випадок, [коли] був виконаний вирок щодо засуджених до 10 років позбавлення волі, а фактично цих людей (прізвища їх не пам'ятаю, чоловік з дружиною) помилково розстріляли, оскільки у приписі помилково було вказано, що вони засуджені до ВМП.

Мені пригадується також факт, коли Карамишев на мої заяви про те, що не можу привести до виконання над низкою осіб, засуджених трійкою до ВМП, оскільки прізвища не сходяться 3 обвинуваченими, що утримуються в тюрмі. Все ж Карамишев викликав мене і колишнього начальника тюрми Штерна та наказав Штерну видати арештованих, а мені отримати ї для виконання вироку. При цьому Карамишев заявив: «Все одно і цих, і інших доведеться розстріляти, так що не треба розбиратися в прізвищах, беріть і розстрілюйте, а потім розберемось» ${ }^{24}$.

Особливо значних масштабів у роботі трійки набуває фальшування слідчих документів, протоколів допитів, очних ставок, обвинувальних висновків, показань. При величезній кількості справ, які вели слідчі інакше і не могло бути. Підслідних примушували підписувати заздалегідь вигадані показання, у тому числі і методами фізичного та морального тиску, а потім їх вносили у формулювання обвинувачень.

Секретар-машиністка Н.I. Суліна на допиті 15 січня 1940 р. свідчила наступне: «...Протоколи засідань трійки я друкувала під диктовку секретаря трійки Шейнберга і мобілізованих для роботи по трійці Чорнобильського і Богуславського. Були такі випадки, коли... Шейнберг велів мені друкувати протоколи допитів, обвинувальні висновки та інші матеріали справи, 3 них [я] вибирала

\footnotetext{
${ }^{21}$ ГДА СБУ. Ф. 5. Спр. 67990. Т. 5. Арк. 226-228.

${ }^{22}$ Ibid. Арк. 229.

${ }^{23}$ Ibid. Арк. 233.

${ }^{24}$ Ibid. Арк. 202.
} 
компрометуючі матеріали та установочні дані, за якими я друкувала протоколи засідань трійки...» ${ }^{25}$.

Старша машиністка трійки Л.П. Февральська навела ще більш вражаючі факти: «Можу ще доповнити наступними фактами: були дуже розповсюджені випадки, коли, друкуючи протоколи засідань трійки про ту чи іншу людину, згідно матеріалів справи доводилось дописувати в обвинувальній частині те, чого в матеріалах справи не було. Особливо часто багатьом дописували стандартні фрази: «проводив антирадянську агітацію проти заходів партії та уряду» і «розповсюджував провокаційні чутки про скору загибель Радянської влади». Все це робилося за вказівками Карамишева.

Як мені було відомо від Шейнберга, що Карамишев заявляв йому про необхідність у протоколах засідань трійки про того чи іншого вже засудженого трійкою за ВМП розширяти обвинувальну частину протоколу, оскільки для засудженого до ВМП незручно вміщувати у протоколи так мало матеріалів. У цих випадках добавлялись ці стандартні фрази...» ${ }^{26}$. Тобто, обвинувачення базувалося на вигадках і, так би мовити, «творчій фантазії друкарок і співробітників трійки.

Мали місце непоодинокі випадки, коли людей розстрілювали до формального рішення трійки, а потім заднім числом оформляли необхідні документи на них для трійки. Та ж Февральська свідчила: «...такі випадки були, коли вироки виконували до підписання протоколів всіма членами трійки. На доказ цього можу навести наступний факт: я друкувала протокол засідання трійки і за моїми кількома віддрукованими сторінками інша машиністка в цей же час друкувала виписки.

Після закінчення друкування протоколу і виписок я друкувала приписи, які підписувалися Карамишевим або Поясовим (заступник начальника УНКВС - Авт.) і передавалися коменданту для виконання вироку.

Протокол засідання трійки на осіб, вирок стосовно яких уже був виконаний, продовжував оформлятись, тобто схематизувався, переплітався, а потім, днів [через] 8-10 підписувався членами трійки. Повинна відзначити, що протоколи засідання трійки ніколи не підписувалися в приміщенні УНКВС членами трійки, а секретар трійки Шейнберг, зібравши по декілька протоколів, возив їх за місцем роботи, тобто Старигіну в обком партії та Ланчуковському в облпрокуратуру» ${ }^{27}$.

Такий порядок роботи трійки дозволяв іноді чекістам зводити особисті рахунки. Так, директор Скадовської школи Н.Н. Трубій звинуватив помічника начальника Миколаївського УНКВС Гончарова у вербовці його для роботи на польську розвідку та написав заяву про це до НКВС УРСР. У результаті Трубій був заарештований. Піддавши тортурам, Трубія примусили відмовитися від своєї заяви і визнати іï вигадкою, адже Гончаров був у дружніх стосунках 3 Карамишевим. Л.П. Февральську пізно вночі викликали до управління НКВС друкувати протокол очної ставки між Трубієм і Гончаровим. На допиті Февральська розповідала наступне:

«...Протокол очної ставки між Гончаровим і Трубієм носив наступний характер. Спочатку Трубій визнавав, що саме він писав заяву на Гончарова, а потім від цього відмовився, заявляв, що писав заяву під його диктовку інший з метою скомпрометувати Гончарова.

Копії цих двох заяв із супроводжувальним листом на адресу Києва і протокол очної ставки я віддала Чайковському (керівник секретаріату УНКВС - Авт.).

Наступного дня я друкувала припис коменданту УНКВС про виконання вироку над Трубієм.

Питання: Значить Трубій був наступного дня розстріляний без рішення трійки?

Відповідь: На повістці, складеній на засіданні трійки у справі Трубія була помітка Карамишева «розстріляти», але засідання трійки не було ні до того, як я друкувала припис, ні після

\footnotetext{
${ }^{25}$ Ibid. Арк. 276.

${ }^{26}$ Ibid. Арк. 288.

${ }^{27}$ Ibid. Арк. 285.
} 
того. Звідси... ясно, що він був розстріляний без рішення трійки...» ${ }^{28}$.

Далі був виявлений цікавий факт - припис коменданту УНКВС, надрукований Февральською, був підмінений іншим. На повторному допиті 25 січня 1940 р. слідчий пред’явив їй повістку:

«Питання: ...Скажіть, Ви цей припис друкували?

Відповідь: Ще раз стверджую, що друкувала припис на ім'я коменданта УНКВС про приведення вироку над обв[инуваченим] Трубієм до виконання, i саме наступного дня після друкування протоколу очної ставки між обвинуваченим Трубієм і к[олишнім] пом[ічником] нач[альника] УНКВС Гончаровим.

Пред’явлений мені припис на ім'я коменданта УНКВС про приведення вироку до виконання над обвинуваченим Трубієм Нестором Назаровичем я не друкувала, тобто я друкувала припис, в якому було перелічено не менше десяти чоловік обвинувачених, у тому числі і обв[инувачений] Трубій.

Пред’явлений мені припис, як я знаю, не друкували й інші машиністки, які працюють зі мною.

Узагалі, крім мене, ніхто з машиністок не друкував [цей] припис на ім'я коменданта УНКВС. Хто ж друкував пред'явлений мені припис, сказати не можу» ${ }^{29}$.

Під час оформлення слідчими справ на трійку мали місце непоодинокі випадки підробки документів, зміни дат арешту тощо. Так, наприкінці червня 1938 р. помічник начальника II відділення IV відділу (СПВ) УНКВС П.Д. Козачук отримав завдання від Трушкіна виїхати у НовоТроїцький район у радгосп ім. Фрунзе, в якому група «ворогів народу» скоїла диверсійний акт отруїла 503 ягнят. У результаті були заарештовані директор вівцерадгоспу Бабаєв, ветлікар Брант, старший зоотехнік Беккер і веттехнік Наместюк (як виконавець диверсії). Допити й оформлення протоколів провадив Козачук, у цьому брав участь і Трушкін. Після застосування «конвеєра»й інших засобів фізичного впливу, Бабаєв надав свідчення про існування у радгоспі диверсійної групи.

На допиті 16 січня 1940 р. Козачук свідчив: «Отримавши від Бабаєвва показання, я склав протокол його допиту і показав його Трушкіну, який перекреслював декілька разів протокол, вставляв у протокол те, чого обвинувачений Бабаєв не розповідав.

Скоригований Трушкіним протокол Бабаєва, був мною підписаний, але не надрукований, оскільки я отримав 22 серпня 1938 р. розпорядження Карамишева про виїзд на нове [місце] призначення в Компаніївський район» ${ }^{30}$.

23 серпня Козачук здав справи і виїхав у район, а справа Бабаєва й інших була передана новому слідчому - Лейзеровському.

У подальшому ретельне розслідування засвідчило, що зазначена справа була повністю сфальсифікована. Документи про арешти, обшуки, протоколи допитів містили підписи Лейзеровського, датовані останніми числами червня, хоча він отримав справу 22 серпня. Тобто всі вони, включаючи постанову прокурора, виявилися підробленими ${ }^{31}$.

Козачук у своїх свідчення запевнив: «Ознайомившись зі справою і протоколами допитів обвинувачених Бранта, Наместюка і Бабаєва, заявляю, що у справі відсутній протокол допиту Бабаєва, Наместюка і Бранта, яких я особисто допитував у районі і УНКВС, за моїм підписом, а наявні у справі протоколи за підписом Лейзеровського датовані 29, 30 червня і 19 липня є фіктивними, оскільки Лейзеровський у цей період часу не міг їх допитувати, оскільки в районі він не був і справа знаходилася у мене до 22 серпня» . $^{32}$

Під час слідства у справі миколаївських чекістів були виявлені серйозні порушення наказу

\footnotetext{
${ }^{28}$ Ibid. Арк. 284.

${ }^{29}$ Ibid. T. 6. Арк. 1-2.

${ }^{30}$ Ibid. Арк. 21.

${ }^{31}$ Ibid. Арк. 22.

${ }^{32}$ Ibid. Арк. 2.
} 
НКВС СРСР від 17 вересня 1938 р. за № 00606 і циркуляра заступника наркома внутрішніх справ СРСР №189 від 21 вересня 1938 р. Згідно наказу та циркуляру особи української, російської, єврейської та білоруської національностей (насправді, у зазначених документах таких положень немає - Авт.), а також спеціалісти високої кваліфікації, такі як інженери, агрономи, вчителі і т.д. не підлягали розгляду особливою трійкою. У результаті перегляду 1269 повісток на трійку, датованих 3 23 вересня, і закінчуючи 5 листопада 1938 р., з'ясувалося, що особливою трійкою на чолі 3 П. Карамишевим було засуджено 2 інженери, 7 агрономів і 22 вчителя. Крім того, трійкою було засуджено 11 осіб заарештованих після 1 серпня 1938 р., що прямо заборонялося наказом № 00606. У 29 повістках не була вказана спеціальність 33.

Жертвами таких порушень стали завідуючий технічним нормуванням корпусного цеху Барсуков, майстер цеху Чернохатов і начальник ППО заводу № 200 Мацковський, заарештовані 3 групою інженерно-технічних працівників за звинуваченням у здійсненні диверсії (організація пожежі у корпусному цеху). Трушкін наказав виділити їх справу в окреме провадження та передати на розгляд трійки. У повістці зазначили, що Чернохатов і Мацковський були заарештовані 30 липня (насправді перший - 8 серпня, а другий - 3 серпня), а Барсуков - 31 липня (насправді - 3 серпня). Старший слідчий УНКВС Сичков 29 серпня 1939 р. відверто свідчив: «Мацковський дійсно був заарештований 3 серпня 1938 р., але для того, щоб його справу пропустити через трійку без протиріччя з Наказом НКВС СРСР про пропуск через трійку тільки осіб, заарештованих до 1 серпня 1938 р. дійсна дата його арешту - 3.08.1938 р. була виправлена на 30.07.1938 p. і він був засуджений до ВМП, а вся інша частина групи з 7 чоловік була піддана суду Військового Трибуналу, яким усі вони були виправдані »3. У результаті фальсифікації Барсуков, Чернохатов і Мацковський у вересні 1938 р. були засуджені до ВМП, а 4 листопада 1938 р. розстріляні ${ }^{35}$. Їх реабілітували тільки у 1957 р.

Звірення слідством приписів про здійснення вироків з протоколами засідань трійки виявило наступні результати, зафіксовані актом від 19 січня 1940 р. з виконання вироків на ім'я коменданта УНКВС за підписом Карамишева і Поясова із засіданням трійки (табл. 1).

Табл. 1. Звірення приписів про здійснення вироків з протоколами засідань трійки

\begin{tabular}{|l|l|l|}
\hline $\begin{array}{c}\text { Кількість } \\
\text { розстріляних, що були } \\
\text { дописані від руки }\end{array}$ & \multicolumn{1}{|c|}{ ПРОТОКОЛИ: } & \multicolumn{1}{|c|}{ ПРИПИСИ: } \\
\hline$(3)$ & № 3 від 29.09.1938 p. & від 2/X - 38 p. \\
\hline$(13)$ & №2 від 26.09.1938 p. & від 10/X - 38 p. \\
\hline$(17)$ & №1 від 23.09.1938 p. & від 10/X - 38 p. \\
\hline$(4)$ & №1 від 23.09.1938 p. & від 27/IX - 38 p. \\
\hline$(5)$ & № 2 від 26.09.1938 p. & від 1/X - 38 p. \\
\hline$(3)$ & № 1 від 23.09.1938 p. & від 25/IX - 38 p. \\
\hline
\end{tabular}

Таким чином за приписами видно, що вироки виконувалися приблизно на два-три тижні i місяць і пізніше засудження осіб трійкою. Є низка приписів, на яких відсутні дати їх складання...» ${ }^{36}$. Це при тому, що накази НКВС СРСР вимагали іх виконання негайно. Цифри зліва є записами, проставленими в акті від руки й означають кількість розстріляних людей.

На усний запит старшого слідчого УДБ НКВС УРСР Бурдана Миколаївським УНКВС були

\footnotetext{
${ }^{33}$ Ibid. T. 9. Арк. 2.

${ }^{34}$ Ibid. T. 4. Арк. 146.

${ }^{35}$ Ibid. T. 9 . Арк. 4.

${ }^{36}$ Ibid. Арк. 4.
} 
перевірені всі архівні матеріали, що були передані секретаріатом Особливої трійки УНКВС до 1 спецвідділу. Серед переданих до архіву виявилось всього близько 600 других екземплярів повісток на трійку, тобто саме тих, на яких проставлялись особисті підписи членів трійки Старигіна та Ланчуковського. У відповіді від 16 січня 1940 р. за підписом начальника УНКВС по Миколаївській області капітана державної безпеки Юрченка зазначалось: «Оскільки за основу складання трієчних протоколів були взяті перші екземпляри повісток з відмітками рішень по справі голови трійки, кол[ишнього] начальника УНКВС, то ці екземпляри секретаріатом трійки були переплетені, пронумеровані у відповідності з протоколами трійки і разом 3 останніми були здані в 1-й спецвідділ» ${ }^{37}$. Тобто зникло більше половини других екземплярів повісток на трійку, які містили власноручні підписи членів трійки, і збереглися тільки перші екземпляри, де проставлявся підпис лише голови трійки - Карамишева.

Ще одна цікава деталь у маніпуляції документами полягала ось у чому. у 1937-1938 pp. кримінальні справи пересилались через НКВС УРСР до Москви на розгляд «в особливому порядку» (тобто «вищою двійкою» - наркомом внутрішніх справ СРСР та Прокурором СРСР - Aвт.) 3-м відділом УНКВС (контррозвідувальний) в обхід 8-го (облікового) відділення. Лише у 1938 р. 3-м відділом УНКВС (начальник Л. Готовцев) слідчі справи на 470 осіб, знову ж в обхід 8-го відділення разом з так званими альбомами були направлені на розгляд до НКВС УРСР.

У відповіді старшому слідчому УДБ НКВС УРСР Бурдану начальника спецвідділу УНКВС по Миколаївській області Самойленка далі зазначалось: «Після розгляду в Києві справи повернули для зберігання до отримання результатів у справах.

За короткий час після чи за декілька днів до видання наказу № 00606 із НКВС УРСР були повернуті в 3-й відділ і альбоми. У відповідності з альбомами (тобто узагальненими списками - Авт.) 8-м відділенням і були роздані по відділах слідсправи.

Встановити список повернутих справ є неможливим, оскільки повернуті альбоми були розформовані, а справи передані на розгляд трійки. Чи були якісь вказівки з Києва про повернення слідсправ щодо представлення їх на трійку - по моєму ні. Навіть за перевіреними архівними матеріалами 1-го спецвідділу за 1938 р. подібного роду документа не виявлено». Повернуті документи розчинились серед відділів УНКВС.

Загалом створена у відповідності до наказу УНКВС СРСР № 00606 Миколаївська особлива трійка провела 12 засідань. Дати засідань і кількість засуджених наводяться у таблиці, підготовленій 1-м спецвідділом УНКВС по Миколаївській області (Табл. 2).

Табл. 2. Кількість засуджених трійкою УНКВС по Миколаївській області протягом вересня - грудня 1938 p. ${ }^{39}$

\begin{tabular}{|l|l|l|l|l|l|l|l|l|l|l|l|r|}
\hline \multicolumn{1}{|c|}{ Дати і кількість засуджених 1938 p. } & \\
\hline $23 / I X$ & $26 / I X$ & $27 / I X$ & $29 / I X$ & $30 / I X$ & $3 / X$ & $4 / X$ & $8 / X$ & $9 / X$ & $13 / X$ & $26 / X$ & $5 / X I I$ & Всього \\
\hline 110 & 173 & 217 & 109 & 138 & 82 & 126 & 152 & 165 & 64 & 52 & 41 & 1259 чол. \\
\hline
\end{tabular}

17 листопада 1938 р. була ухвалена постанова РНК СРСР і ЦК ВКП(б) «Про арешти, прокурорський нагляд і методи слідства», яка офіційно завершила масові операції. Проте за інерцією співробітники НКВС продовжували використовувати катування, знущання та провокащії, хоча й не в таких масштабах, як раніше, через певну розгубленість і дезорієнтацію.

\footnotetext{
${ }^{37}$ Ibid. Арк. 12.

${ }^{38}$ Ibid. Арк. 35.

39 Довідка начальника 1 спецвідділу УНКВС у Миколаївській області, сержанта держбезпеки Самойлено. № 1231779 від 24 січня 1940 р. // Ibid. Арк. 28.
} 
Виходячи з усього, що відображено у статті, можна зробити наступні висновки.

Початок масових репресій в Україні розпочинається з 4 липня 1937 р., коли на засіданні політбюро ЦККП(б)У були сформовані обласні трійки у складі першого секретаря обкому, начальника обласного УНКВС та обласного прокурора. Миколаївську обласну трійку, членами якої були перший секретар обкому Волков та обласний прокурор Ланчуковський, очолив, вочевидь, начальник Миколаївського управління НКВС капітан державної безпеки Й.Б. Фішер, а 33 березня 1938 р капітан держбезпеки П.В. Карамишев.

Головну роль у проведенні репресивних акцій було відведено міжрайонним оперативним групам чекістів, які були створені в окружних центрах і великих населених пунктах. Всього в УРСР було створено 45 міжрайонних опергруп.

Архівні документи свідчать, що за час після організації Миколаївської області до січня 1938 р. було «опрацьовано» 7175 арештованих. Самі чекісти не задовольнялися наданими лімітами, що надавалися з гори, та вимагали їх збільшення.

Розгляд справ обласними трійками відбувався за спрощеною процедурою, що порушувала громадянські права звинувачених - без участі захисту та самого обвинуваченого, і без права на оскарження вироку. Смертний вирок виконувався негайно.

у другій половині 1938 р. темпи репресій уповільнюються, що було обумовлено демонстрацією відновлення партійного контролю над органами НКВС і перекладання на співробітників НКВС провини у «порушенні соціалістичної законності». Й. Сталін і вище політичне керівництво вважало, що таким тактичним маневром буде знята напруга серед працівників партійно-радянського апарату та загалом у суспільстві. Розпочинаються напівзакриті процесів над чекістами, які, на думку вищого політичного керівництва, повинні були стати цапами-відбувайлами в очах громадян.

Під час вказаних процесів було викрито зловживання службовими обов'язками у вигляді фальсифікації справ і підробки слідчих документів, які часто підписували їх не читаючи і навіть не переглядаючи, внесення до протоколів нових прізвищ, змінювання попередніх рішень. Отримання зізнань за допомогою морального тиску та тортур. Все це свідчить про моральну деградацію та дегуманізацію як виконавців злочинних наказів, так і тих, хто їх віддавав, а також і про повний регрес сталінської соціалістичної системи, яка знецінила людське життя.

\section{Serhii Makarchuk, Mykhailo Fedorenko}

\section{Regressive Result of Anthropological Statistics of the Great Terror in the USSR} (1937-1938)

Abstract: The research focuses on the statistical analysis of regressive results of anthropological statistics on an example of work of the Mykolaiv 'troika'. In particular, researchers have the opportunity to analyze the quantitative and qualitative characteristics of the results of repressive actions, to conduct a source analysis of state security documents of the period of mass repressions regarding their informativeness and degree of completeness, representativeness and reliability, falsification options, etc. The mechanism of functioning of extrajudicial bodies of Stalin's repressions - 'troikas', 'dvoikas', Special Meetings, the role and consequences of the special 'troika', their composition and nature of cases is considered.

The proposed study uses a source that until recently was inaccessible - the materials of the investigation of official activities and crimes of state security officers. For the first time in Ukraine, this array of documents was published in 2017-2018. The basis of scientific 
intelligence is a 13-volume archival-criminal case on the investigation of crimes of officials of the Mykolaiv UNKVD at the final stage of the Great Terror. The collection of documents and materials contains minutes and transcripts of party meetings and operational meetings of regional UNKVD officers, interrogation records, witness statements, inspection materials, etc., which reveal both the procedure for the operation of the 'troika' and methods of falsification of cases. The minutes of court hearings of military tribunals, which considered criminal cases of NKVD officers for violating «socialist legality» during mass operations, entered into scientific circulation. They are found in the archival and criminal cases of the Chekists, some extracts are found in the cases of repressed citizens as an illustration of the activities of investigators.

Keywords: anthropological statistics, USSR, Ukrainian, SSR, Mykolaiv Region, NKVD, Great Terror 1937-1938, mass repressions, 'troika', Special Meeting 